\title{
Expression of the Neural Cell Adhesion Molecule and Polysialic Acid During Early Mouse Embryogenesis
}

\author{
R. Probstmeier, A. Bilz, and J. Schneider-Schaulies \\ Department of Neurobiology, Swiss Federal Institute of Technology Zürich, Zürich, Switzerland
}

The expression of the neural cell adhesion molecule (N-CAM) and $\alpha$ 2-8 linked polysialic acid (PSA), which is believed to be predominantly expressed on N-CAM, was investigated during early embryonic development of the mouse (embryonic days 7.5 to 10.0 ). By immunocytochemistry, in tissue sections, N-CAM and PSA were not detectable at embryonic day $\mathbf{7 . 5}$ but were expressed in the prominent body regions such as somites, unsegmented mesoderm, developing heart, and neuroectoderm at embryonic day 8.0 N-CAM and PSA immunoreactivities were always predominantly associated with the plasma membrane. No tissue could be detected which was positive for PSA but negative for N-CAM. In Western blot analysis of whole embryos, by contrast, only the lightly sialylated and PSA-negative 180 and $140 \mathrm{kD}$ isoforms of $\mathrm{N}$-CAM were present at embryonic day 8.0 and strong expression of PSA-bearing, heavily sialylated N-CAM was not detectable before embryonic day 10.0. In Western blot analysis of N-CAM immunoaffinity purified from whole embryos and digested with neuraminidase as well as in Northern blot analysis, the $120 \mathrm{kD}$ isoform of N-CAM or its corresponding mRNA were not expressed in detectable amounts during the time period investigated. (c) 1994 Wiley-Liss, Inc.

Key words: embryo, mouse, N-CAM, sialic acid

\section{INTRODUCTION}

The neural cell adhesion molecule (N-CAM) is a membrane glycoprotein which influences via homo- or heterophilic binding mechanisms a number of intercellular adhesion events (Cole et al., 1986; Cole and Akeson, 1989; Kadmon et al., 1990a,b; Doherty et al., 1990, 1991 b; Frei et al., 1992). N-CAM is a member of the immunoglobulin superfamily (Barthels et al., 1987; Cunningham et al., 1987) and exists in multiple molecular forms generated either by alternative splicing leading to three main size classes of the molecule with apparent molecular masses of 180,140 , and $120 \mathrm{kD}$ (Cunningham et al., 1983, 1987; Gennarini et al., 1984; Barbas et al., 1988 ) or by different posttranslational modifications such as sulfation and phosphorylation (Sorkin et al., 1984) or glycosylation (Rothbard et al., 1982; Rougon et al., 1982; Walsh et al., 1989; Key and Akeson, 1991). Among the different carbohydrate side chains expressed on N-CAM most attention has been drawn to the high amounts of $\alpha$ 2-8 linked polysialic acid (PSA), oligosaccharides which are thought to be predominantly expressed on N-CAM (Finne et al., 1983) with the $\alpha$ subunit of voltage gated sodium channels as the only known exception (James and Agnew, 1987; Zuber et al., 1992).

In recent years, the influence of PSA on the adhesive properties of N-CAM has been examined in a number of studies. In aggregation assays using cells or membrane vesicles, the presence of PSA leads to a reduced aggregation (Hoffman and Edelman, 1983; Acheson et al., 1991) and an increase of the intercellular space between contacting cells (Rutishauser et al., 1988; Yang et al., 1992). Additionally, PSA increases the rate of N-CAM-dependent neurite outgrowth (Doherty et al., 1990), suggesting that PSA weakens N-CAM-dependent adhesion and thus favors more dynamic cell to cell interactions such as migration or process formation. Furthermore, dependent on the set of adhesion molecules present on the cell surface, removal of PSA can lead to an increased cell to cell adhesion initiated by molecules other than N-CAM. A recent study has demonstrated that removal of PSA from $\mathrm{Ll}$-positive neuronal cells leads to an increase in L1- and a decrease in N-CAM-dependent cell adhesion (Zhang et al., 1992). The amount of PSA

Received March 19, 1993; revised July 15, 1993; accepted July 16, 1993.

Address reprint requests to Rainer Probstmeier, Department of Neurobiology, Swiss Federal Institute of Technology Zürich, Hönggerberg, 8093 Zürich, Switzerland.

Jürgen Schneider-Schaulies is presently at Institute of Virology and Immunobiology, University of Würzburg, Versbacherstr. 7, 8700 Würzburg, F.R.G. 
present on N-CAM is developmentally regulated in different species. As has been shown by Western blot analysis, during early embryogenesis of chicken and frog $\mathrm{N}$-CAM is expressed in its lightly sialylated forms (L$\mathrm{N}-\mathrm{CAM}$ ), during late embryonic development predominantly in its heavily sialylated forms (H-N-CAM), while during early postnatal development $\mathrm{H}-\mathrm{N}-\mathrm{CAM}$ is again converted to L-N-CAM (Levi et al., 1987; Sunshine et al., 1987). The scheme for a general conversion of $\mathrm{H}-$ to $\mathrm{L}-\mathrm{N}-\mathrm{CAM}$, at least during postnatal development, is clearly too simplistic as it has been shown that H-NCAM is also expressed in particular parts of the body during adulthood, for example in the hypothalamo-neurohypophysal system (Theodosis et al., 1991), optic nerve, retina (Bartsch et al., 1990), and the olfactory bulb (Miragall et al., 1988, 1990).

While data on the expression pattern of different $\mathrm{N}$-CAM isoforms during early embryogenesis are available for chicken and frog (Levi et al., 1987; Sunshine et al., 1987) comparable data for mammals are missing. Here, we have investigated the expression of N-CAM and PSA during early embryonic development of the mouse using Northern and Western blot analysis and indirect immunohistology. By Western blot analysis of embryonic tissue from different stages we obtained essentially the same results as described in the literature for other species (Levi et al., 1987; Sunshine et al., 1987), i.e. that at early developmental stages such as embryonic day (E) 8.0 only L-N-CAM was detectable. In contrast, by immunohistology the presence of substantial amounts of PSA could be demonstrated already at E 8.0 suggesting that PSA is carried by other molecules than N-CAM.

\section{MATERIALS AND METHODS Animals}

NMRI mice were maintained at the departmental animal facility. For staging of embryonic mice, the day at which a vaginal plug was found was designated day 0 (E0).

\section{Antibodies}

The following antibodies were used: Immunoaffinity purified polyclonal antibodies to N-CAM which were obtained by adsorbing sera onto purified antigen coupled to Sepharose 4B and elution at low $\mathrm{pH}$ (Tacke et al., 1987), monoclonal antibody $\mathrm{H} 28$ to an extracellular epitope of N-CAM (Rougon et al., 1982), and monuclonal antibody 735 which reacts with $\alpha$ 2-8 linked polysialic acid present in the highly sialylated form of N-CAM (Frosch et al., 1985).

For indirect immunofluorescence, goat anti-rabbit immunoglobulin antibodies coupled with fluoresceinisothiocyanate (FITC) were purchased from Dakopatts
(Hamburg, FRG) and Miles (Munich, FRG). For Western blot analysis, goat anti-rabbit or sheep anti-mouse immunoglobulin antibodics coupled to alkaline phosphatase were purchased from Cappel (Denkendorf, FRG) and Promega-Biotech (Madison, WI, USA).

\section{Immunohistology}

Embryos (E 8.0 to $E$ 11.0) were dissected in Hank's balanced salt solution (HBSS), washed in phosphate buffered saline, pH 7.4 (PBS), and fixed for 30 min (for E 8.0 and E 8.5) or $1 \mathrm{hr}$ (for E 9.0 and E 9.5) in $4 \%$ formaldehyde in PBS. Embryos were washed consecutively in PBS for $10 \mathrm{~min}$, incubated in a $10 \%$ sucrose solution for 3 (for $E 8.0$ to $E$ 8.5) or $16 \mathrm{hr}$ (for $E 9.0$ to E 11.0 ) and in a $20 \%$ sucrose solution for $24 \mathrm{hr}$ at $4^{\circ} \mathrm{C}$. Sucrose solutions were in PBS containing $0.01 \% \mathrm{NaN}_{3}$. Embryos were then embedded in OCT (Jung, Nussloch, FRG) and shock-frozen in 2-methylbutane. Sections, 10 $\mu \mathrm{m}$ thick, were cut in a Frigocut 2700 (Jung, Nussloch, FRG), transferred onto glass coverslips coated with polyL-lysine, and dried for $60 \mathrm{~min}$ at room temperature. Sections were then blocked for $15 \mathrm{~min}$ at room temperature with PBS containing $1 \%$ horse serum and $0.1 \%$ bovine serum albumin (BSA) (blocking buffer), washed for 5 min in PBS containing $0.1 \%$ BSA (PBS-BSA), incubated for $20 \mathrm{~min}$ with the first antibody (diluted in blocking buffer), washed three times for $5 \mathrm{~min}$ in PBS-BS $\Lambda$, incubated for $20 \mathrm{~min}$ with FITC-conjugated second antibody (diluted in blocking buffer), washed again in PBS-BSA, and embedded in glycerol/PBS (1:1, v/v). In control experiments the incubation with the first antibody was omitted.

\section{Western Blot Analysis}

Embryos were dissected out of the extraembryonic tissue in $\mathrm{Ca}^{2+}$ - and $\mathrm{Mg}^{2+}$-free HBSS and stored at $-80^{\circ} \mathrm{C}$.

Embryonic tissue was homogenized $(1: 5 ; \mathrm{w} / \mathrm{v})$ in $50 \mathrm{mM} \mathrm{NaH} \mathrm{PO}_{4} / \mathrm{Na}_{2} \mathrm{HPO}_{4}, 100 \mathrm{mM} \mathrm{NaCl}, 0.2 \mathrm{mM}$ $\mathrm{CaCl}_{2}, 0.2 \mathrm{mM} \mathrm{MgCl}, 1 \%$ Triton X-100, pH 7.4 containing $1 \mathrm{mM}$ spermidine and the protease inhibitors iodoacetamide $(0.8 \mathrm{mM})$, phenylmethylsulfonylfluoride ( 1 $\mathrm{mM})$, soybean trypsin inhibitor $(16 \mu \mathrm{M})$, and aprotinin $(3.5 \mu \mathrm{M})$, and solubilized for $90 \mathrm{~min}$ at $4^{\circ} \mathrm{C}$. The solubilizate was centrifuged at $10,000 \mathrm{~g}$ for $10 \mathrm{~min}$ and the protein concentration of the supernatant determined according to Bradford (1976) and adjusted to 1.0 to 1.5 $\mathrm{mg} / \mathrm{ml}$ with the buffer used for homogenization. Sample buffer for sodium dodecylsulfate polyacrylamide gel electrophoresis (SDS-PAGE) was added and samples were either boiled for $1 \mathrm{~min}$ or incubated for $30 \mathrm{~min}$ at room temperature. Western blot analysis was carried out as described by Towbin et al. (1979) and modified by Faissner et al. (1985). Proteins separated by SDS-PAGE 
using 6\% slab gels (Laemmli, 1970) were transferred for $1 \mathrm{hr}$ at $0.25 \mathrm{~A}$ to nitrocellulose filters. To visualize transferred proteins, filters were incubated with a $0.2 \%$ solution of Ponceau $\mathrm{S}$ in 3\% trichloroacetic acid for $1 \mathrm{~min}$ at room temperature and subsequently washed in water. Filters were then washed for $20 \mathrm{~min}$ in Tris-bufferedsaline (TBS; $50 \mathrm{mM}$ Tris- $\mathrm{HCl}, 100 \mathrm{mM} \mathrm{NaCl}, \mathrm{pH}$ 7.4) and incubated for $60 \mathrm{~min}$ in blocking buffer (TBS, 2\% BSA, $10 \%$ hemoglobin). Filters were then incubated overnight at room temperature with first antibodies (diluted in blocking buffer), washed four times for $15 \mathrm{~min}$ in TBS containing $0.2 \%$ Tween 20 , and then incubated with the second, alkaline phosphatase-coupled antibody (diluted in blocking buffer) for $1 \mathrm{hr}$ at room temperature. Antibodies were visualized with $3.3 \mathrm{mg}$ nitro-blue-tetrazolium, $1.6 \mathrm{mg}$ 5-bromo-4-chloro-3-indolylphosphate per $10 \mathrm{ml} 100 \mathrm{mM}$ Tris- $\mathrm{HCl}, 5 \mathrm{mM} \mathrm{MgCl}_{2}, \mathrm{pH} 9.5$.

\section{Neuraminidase Digestion of N-CAM}

Embryos were homogenized, incubated in homogenization buffer, and centrifuged as described in the previous section. The protein concentration of the supernatant was adjusted to $5 \mathrm{mg} / \mathrm{ml}$ with homogenization buffer. Five hundred microliters of this solution were mixed with $100 \mu$ l of a $30 \%$ suspension of Sepharose $4 \mathrm{~B}$ beads coupled with $90 \mu \mathrm{g}$ of a monoclonal antibody to N-CAM (Rougon et al., 1982) and incubated overnight in $2.5 \mathrm{ml}$ Eppendorf tubes on a shaker at $4^{\circ} \mathrm{C}$. Beads were washed three times in homogenization buffer in which the $\mathrm{NaCl}$ concentration was increased to $400 \mathrm{mM}$, mixed with $150 \mu \mathrm{l}$ of sodium acetate buffer $(50 \mathrm{mM}$ sodium acetate, $100 \mathrm{mM} \mathrm{NaCl}, 3 \mathrm{mM} \mathrm{MgCl}, 2 \mathrm{mM}$ $\mathrm{CaCl}_{2}, 1 \%$ Triton $\mathrm{X}-100, \mathrm{pH} 6.0$ ) and $60 \mu \mathrm{l}$ of a neuraminidase solution in $50 \mathrm{mM}$ sodium acetate, $\mathrm{pH}$ 5.5 (from Vibrio cholerae, 1 unit/ml; Serva, Heidelberg, FRG), and incubated for 3 to $4 \mathrm{hr}$ at $37^{\circ} \mathrm{C}$. In control experiments, instead of the neuraminidase solution $60 \mu \mathrm{l}$ of $50 \mathrm{mM}$ sodium acetate, $\mathrm{pH} 5.5$ were added. Beads were then washed three times with homogenization buffer and $100 \mu \mathrm{l}$ of SDS-sample buffer was added. The bead suspension was boiled for $1 \mathrm{~min}$, beads pelleted by a $10 \mathrm{~min}$ centrifugation at $5,000 \mathrm{~g}$, and the supernatant used directly for SDS-PAGE and Western blot analysis.

\section{Preparation of Poly $(A)^{+}{ }^{R N A}$ and Northern Blot Analysis}

Total RNA was extracted according to Chirgwin et al. (1979). In brief, tissues were homogenized in $4 \mathrm{M}$ guanidinium isothiocyanate, $0.5 \%$ sodium $\mathrm{N}$-laurolylsarcosine, $25 \mathrm{mM}$ sodium citrate, $0.1 \mathrm{M}$ 2-mercaptoethanol, pH 7.0 (GITC), layered on a $\mathrm{CsCl}$ cushion (1.7 $\mathrm{g} / \mathrm{ml}$ ), and total RNA pelleted by $80,000 \mathrm{~g}$ centrifugation for $18 \mathrm{hr}$. Poly(A) ${ }^{+}$RNA was selected by affinity purification on an oligo(dT)-cellulose column (mRNA puri- fication kit; Pharmacia, Freiburg, FRG) according to the manufacturer's device. Poly $(\mathrm{A})^{+}$RNA was separated on a $1 \%$ agarose gel containing $6.3 \%$ formaldehyde and blotted on Hybond $\mathbf{N}$ filter (Amersham, Braunschweig, FRG).

The ${ }^{32} \mathrm{P}$-labclled T7 RNA polymerase transcript of plasmid pM 1.3 linearized with BamHI was used as hybridization probe for N-CAM (Goridis et al., 1985). Invitro-transcription was performed according to Melton et al. (1984) for $1 \mathrm{hr}$ at $37^{\circ} \mathrm{C}$ using $1 \mu \mathrm{g}$ template DNA and 10 units of T7 RNA polymerase (Boehringer, Mannheim, FRG) in $40 \mathrm{mM}$ Tris- $\mathrm{HCl}, \mathrm{pH} 7.4$ containing 6 $\mathrm{mM} \mathrm{MgCl} 2,10 \mathrm{mM}$ dithiothreitol, 1 unit/ $\mu$ l RNasin, 0.5 $\mathrm{mM}$ of ATP, GTP, and UTP, $12 \mu \mathrm{M}$ CTP, and $50 \mu \mathrm{Ci}$ alpha- ${ }^{32} \mathrm{P}-\mathrm{CTP}$ (specific activity $400 \mathrm{Ci} / \mathrm{mM}$ ). After digestion of the template DNA with 1 unit RQ-DNase (Promega, Madison, WI, USA) for $15 \mathrm{~min}$ at $37^{\circ} \mathrm{C}$, the riboprobe was extracted with phenol/chloroform (1:1) and pelleted with $70 \%$ ethanol at $-20^{\circ} \mathrm{C}$. The $1.4 \mathrm{~kb}$ PstI/PstI fragment of pGAPDH (Fort et al., 1985) labelled with $\alpha-{ }^{32} \mathrm{P}-\mathrm{dCTP}$ (random priming kit; Boehringer, Mannheim, FRG) was used as hybridization probe for glyceraldehyde-3-phosphate-dehydrogenase (GAPDH). Hybridization was performed according to Maniatis et al. (1982) for $24 \mathrm{hr}$ at $45^{\circ} \mathrm{C}$ (for pGAPDH) or $55^{\circ} \mathrm{C}$ (for $\mathrm{pM} \mathrm{1.3)}$ in hybridization buffer consisting of $50 \%$ formamide, $5 \times$ Denhardt's, $6 \times$ SSPE, 250 $\mu \mathrm{g} / \mathrm{ml}$ carrier RNA, and $0.5 \%$ SDS.

\section{RESULTS}

To analyze the expression pattern of N-CAM and PSA in embryonic mice from days 8.0 to 11.0 we used Western and Northern blot analyses as well as indirect immunohistology.

\section{Western Blot Analysis}

Crude detergent extracts of total embryos from $\mathrm{E}$ 8.0 to 11.0 were separated by SDS-PAGE and the $\mathrm{N}$-CAM forms present analyzed in Western blots using immunoaffinity purified polyclonal antibodies to N-CAM (Fig. 1A, lanes a) and the monoclonal 735 antibody which specifically recognizes the unusual $\alpha 2-8$ linked polysialic acid present in the highly sialylated form of N-CAM (Fig. 1A, lanes b). At E 8.0, 8.5, and 9.0 two distinct bands with molecular weights (MWs) of 180 and $140 \mathrm{kD}$ were detectable with the polyclonal N-CAM antibody. At E 8.0, no signal was detectable with the 735 antibody. A weak 735 immunoreactivity in the high molecular weight range $(>180 \mathrm{kD})$ was first detectable at E 8.5 and 9.0. It has to be noted that the polyclonal N-CAM antibody used is less sensitive in the detection of H-N-CAM in comparison to L-N-CAM and, therefore, did not allow the detection of low amounts of $\mathrm{H}-\mathrm{N}-\mathrm{CAM}$. At E 9.5, the staining pattern of the poly- 

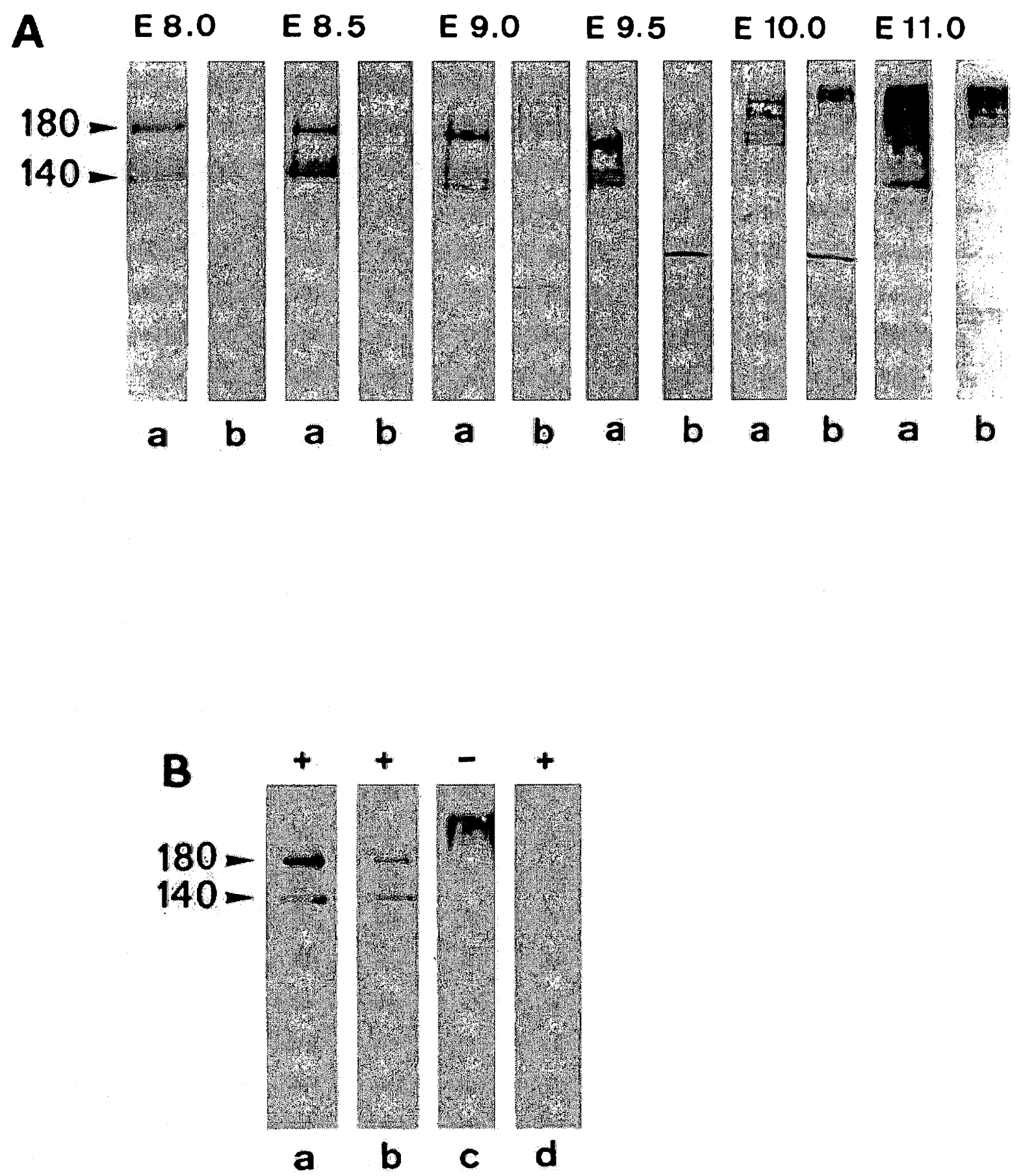

Fig. 1. Western blot analysis of crude membrane solubilizates (A) and immunoaffinity purified N-CAM from whole mouse embryos (B). A: Tissue extracts from 8.0-, 8.5-, 9.0-, 9.5-, $10.0-$, and 11.0-day-old embryos were analyzed with polyclonal antibodies to N-CAM (a), and the monoclonal antibody 735 to PSA (b). The intense bands in the lower molecular weight range visible in same lanes were also detectable when body directed against mouse IgGs. B: N-CAM was immunoaffinity purified from tissue extracts of E 10.0 to $10.5(a, c, d)$ and $E 11.0$ to 11.5 (b) and treated without (-) or with neuraminidase $(+)$. N-CAM $(a, b)$ and PSA $(c, d)$ were detected with polyclonal N-CAM antibodies and the monoclonal antibody 735 , respectively. Molecular weights in $\mathrm{kD}$ for transferred proteins were incubated only with the second antiN-CAM 180 and N-CAM 140 are indicated at the left margins. 
clonal N-CAM antibody became more diffuse and showed a smear from 140 to about $250 \mathrm{kD}$ but distinct bands with MWs of 180 and $140 \mathrm{kD}$ were still visible. With the 735 antibody, again, only a weak staining was obtained at higher MWs. At E 10.0 and 11.0, the polyclonal antibody stained a smear between 140 and about $250 \mathrm{kD}$ and no clear bands of 180 and $140 \mathrm{kD}$ could be identified. The 735 antibody recognized only the highest portion of this smear. This could be due to the fact that for antibody binding a chain length of seven to eight $\alpha$ 2-8-linked sialic acid units is necessary (Finne et al., 1987) which may be absent on some sialylated N-CAM molecules.

When N-CAM immunoaffinity purified from $\mathrm{E}$ 10.0 and 11.0 was treated with neuraminidase two distinct bands with MWs of 180 and $140 \mathrm{kD}$ were detected (Fig. 1B, lanes a, b). 735 antibody still recognized a smear in the high MW range when N-CAM from E 10.0 or 11.0 was incubated in the buffer used for digestion and the enzyme omitted (Fig. 1B, lane c, for E 10.0 to 10.5). After digestion with neuraminidase no signal could be obtained with 735 antibody (Fig. 1B, lane d). It is known that PSA is sensitive to heat treatment (see, for example, Husmann et al., 1989) and, therefore, after addition of SDS-sample buffer, solubilizates were usually boiled for only $1 \mathrm{~min}$. Alternatively, E 8.0 solubilizates were incubated for $30 \mathrm{~min}$ at room temperature and again no signal with the 735 antibody was detectable (not shown).

At none of the developmental stages tested was the $120 \mathrm{kD}$ form of N-CAM observed.

\section{Northern Blot Analysis}

'To confirm the results obtained by Western blots, Northern blot analyses were carried out using poly (A) ${ }^{+}$RNA from 9.0-, 10.0-, and 11.0-day-old em. bryos. For detection of N-CAM specific mRNAs we used the plasmid pM 1.3 which contains 600 base pairs of the $3^{\prime}$ end of the N-CAM cDNA (Goridis et al., 1985). The main transcription products in the adult mouse brain are mRNAs of $7.4,6.7,5.2$, and $2.9 \mathrm{~kb}$. The $7.4 \mathrm{~kb}$ form codes for the 180 , the 6.7 for the 140 , and the 5.2 and 2.9 for the $120 \mathrm{kD}$ form of N-CAM (Barbas et al., 1988). At E 9.0, 7.4, and $6.7 \mathrm{~kb}$ mRNAs of N-CAM were detectable (Fig. 2A, lane 1), the $7.4 \mathrm{~kb}$ mRNA in such low amounts that the corresponding band is hardly visible on the photograph. In poly $(\mathrm{A})^{+}$RNA preparations of $E 10.0$ and 11.0 the same two mRNAs were clearly detectable but no signal was obtained for the two mRNAs coding for the $120 \mathrm{kD}$ form of N-CAM (Fig. $2 \mathrm{~A}$, lanes 2,3$)$. In poly $(\mathrm{A})^{+}$preparations of adult mouse brain all four main mRNAs were present (Fig. 2A, lane 4).

To investigate the quality and the amount of the
$\operatorname{poly}(\mathrm{A})^{+}$RNA used for hybridization with the N-CAM specific probe the same filter as shown in Figure 2A was rehybridized with a probe specific for GAPDH which should be present in all preparations in about equal amounts. As shown in Figure 2B this was indeed the case.

\section{Immunofluorescence Localization of N-CAM and PSA in Sections of 7.5- to 9.5-day-old Mouse Embryos}

In order to investigate the tissue distribution of N-CAM and PSA we analyzed their expression pattern in sections of 7.5- to 9.5-day-old mouse embryos. The aim of this part of our study was not a detailed description of the expression pattern but an analysis of the bulk distribution of N-CAM and PSA at the embryonic stages tested. Thus, we will predominantly refer to tissues which represent the bulk of the whole embryo, such as the developing nervous system and mesodermal derivatives.

Embryonic day 7.5. At E 7.5 the embryo shows the first signs of organogenesis and is characterized by the formation of the notochord and the appearance of the neural or medullar plate. Fore- and hindgut regions can be identified as well as the heart mesoderm. Somites are not yet formed at this stage.

Neither N-CAM nor PSA was detectable at this stage of development (not shown).

Embryonic day 8.0 to 8.5. The 8.0-day-old mouse embryo is characterized by one to seven somites. Fore- and hindgut pocket develop further, while the midgut region is still open. The heart tissue can be separated into peri-, endo-, and myocardium. The first aortic arch appears and the neural plate is converted to neural folds. The 8.5-day-old embryo contains eight to 12 somites. The midgut region is still open. The neural folds close at somite level 4 to 5 and the paired heart primordia fuse. The embryo starts to turn, thereby converting the neuroectoderm to the outside of the U-shaped embryo.

N-CAM was strongly expressed in the myocardium of the developing heart (Figs. 3A,D), in epithelial somites (Figs. 3B,E), and the segmental plate (Figs. $3 C, D)$. An intermediate level of expression was found in the neuroectoderm such as the telocoel (Figs. 3A,D) and a low expression in the head mesenchyme. N-CAM could not be detected in the epithelial cells of the foreand hindgut (Figs. 3C,D), the endocardium of the developing heart (Figs. 3A,D), and extraneuroectodermal ectoderm which surrounds the somites (Figs. 3B,D).

In contrast to Western blot analysis where PSA was not detectable at E 8.0 (Fig. 1, lanes 1 and 2) and only in very low amounts of $E 8.5$, by immunohistochemistry PSA was strongly detectable already at E 8.0 in somites (Figs. 3H,I,K,L) and the neuroectoderm and, at a lower 
A

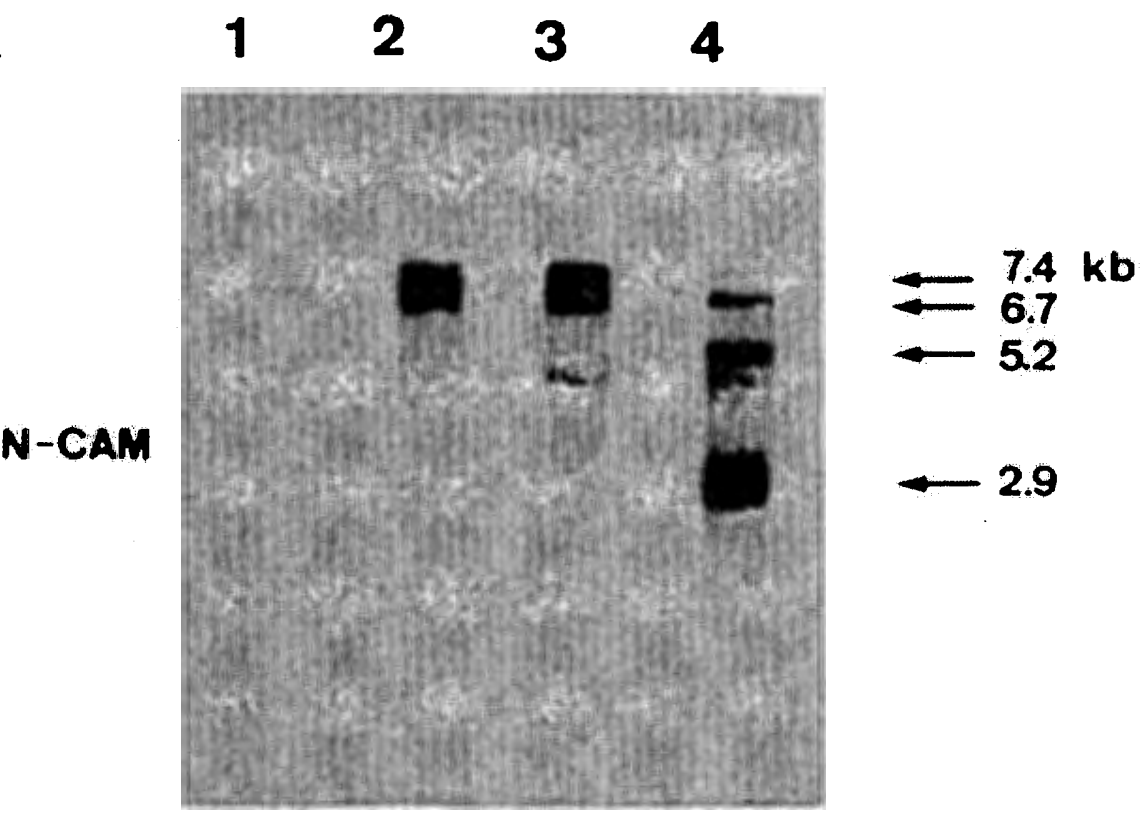

B

2

3

4

GAPDH

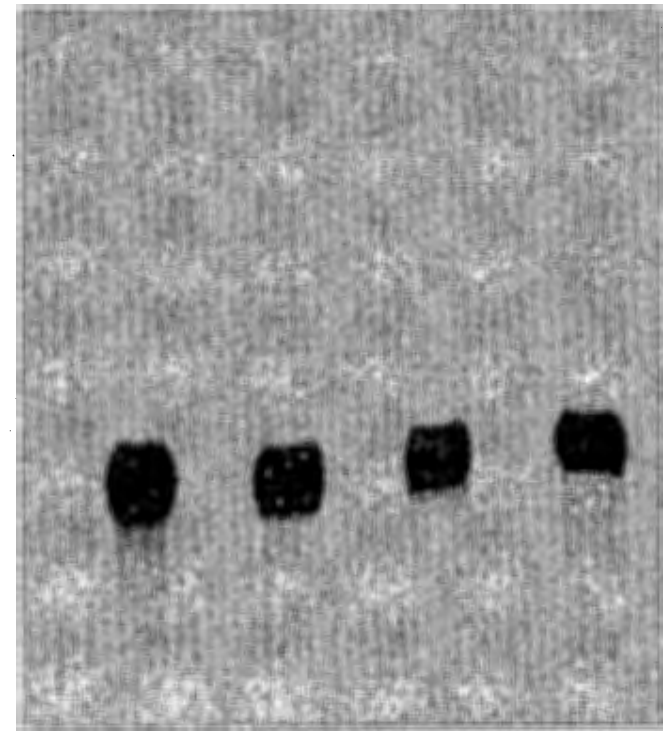

Fig. 2. Northern blot analysis of poly $(A)^{+}$RNA purified from 9.0- (lane 1), 10.0- (lane 2), 11.0- (lane 3) day-old mouse embryos and adult mouse brain (lane 4). Poly (A) ${ }^{+}$RNA was separated on a $1 \%$ agarose gel containing $6.3 \%$ fornaldehyde,

level, in the head mesenchyme (Figs. 3G,J). As for $\mathrm{N}-\mathrm{CAM}$, no PSA was detectable in the endocardium and extraneuroectodermal ectoderm (not shown). A high background labelling resulting from the use of secondary antibodies to mouse immunoglobulins on mouse tissue blotted on Hybond $\mathrm{N}$ filter and hybridized to a specific riboprobe for N-CAM (A) or GAPDH (B). Sizes in kb of N-CAMor GAPDH-specific mRNAs are indicated at the right margins.

was found on endodermal cells of the fore- and hindgut which did not allow the localization of PSA on these cells.

N-CAM and PSA immunoreactivities were always predominantly associated with the plasma membrane and 

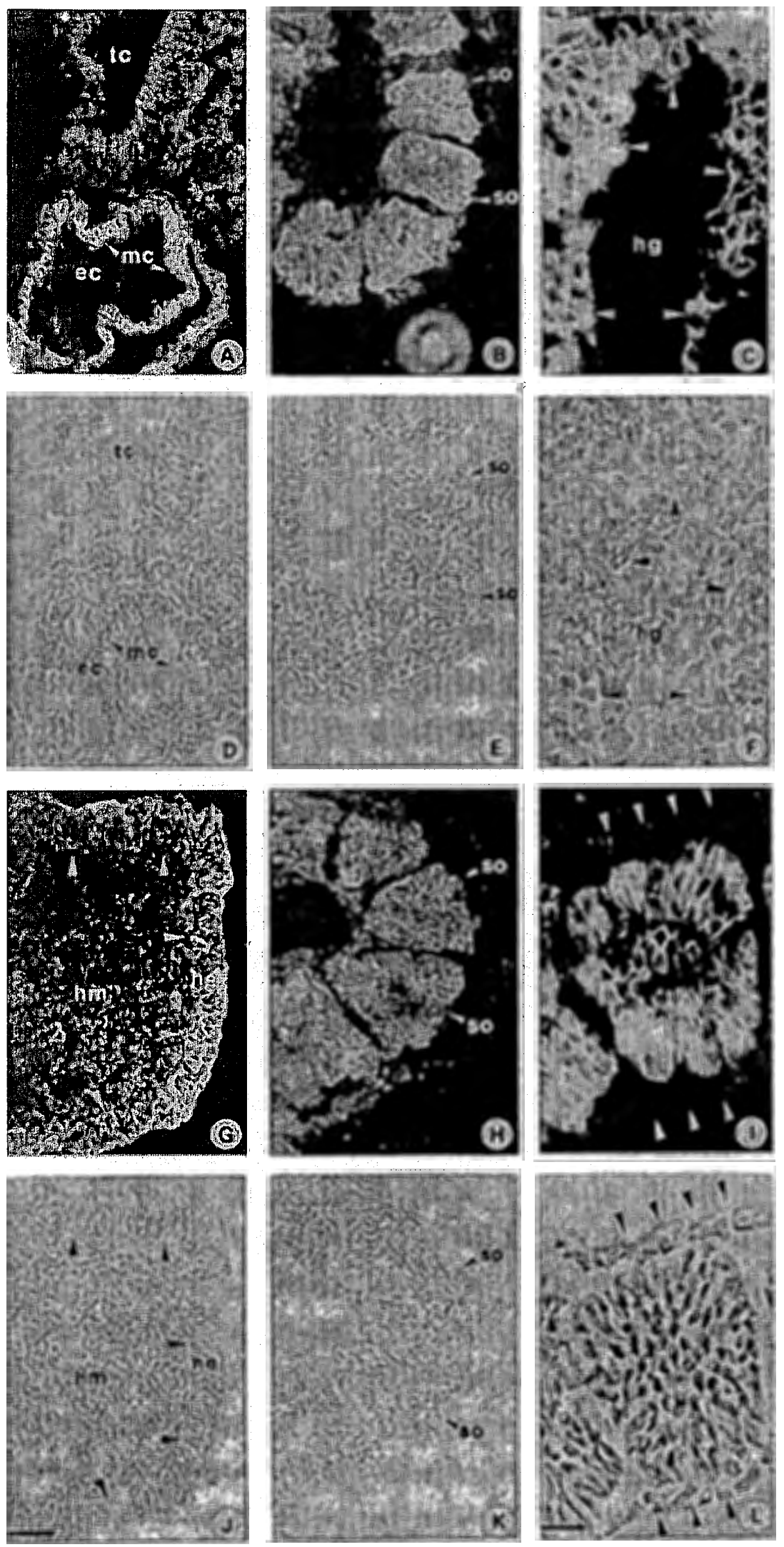

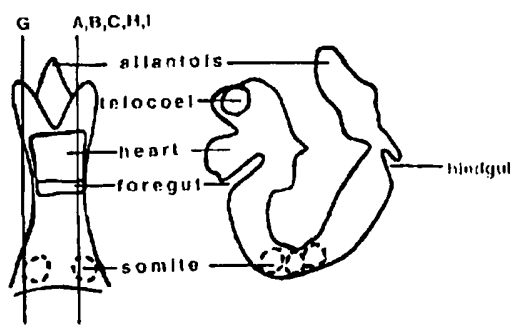

Fig. 3. Immunohistological localization of N-CAM (A, B, C) and PSA (G, H, I) in sagittal sections of 8.0-(G, I) and 8.5$(\mathrm{A}, \mathrm{B}, \mathrm{C}, \mathrm{H})$ day-old mouse embryos. $D, E, F, J, K$, and $L$ are the corresponding phase-contrast micrographs to fluorescence images in $A, B, C, G, H$, and $I$, respectively. A,D: Head and heart region of an 8.5-day-old embryo; the myocardium is indicated by arrowheads. B,E: Somite region of an 8.5-day-old embryo; two somites are indicated by arrowheads. The posterior part of the embryo is oriented to the top. C,F: Hindgut region of an 8.5-day-old embryo. Arrowheads demarcate the borderline between endoderm and the surrounding mesenchyme. G,J: Head region of an 8.0-day-old embryo; arrowheads demarcate the borderline between head mesenchyme and neuroectoderm. H,K: Somite region of an 8.5-day-old embryo; two somites are indicated by arrowheads. The posterior part of the embryo is oriented to the top. I, L: Second somite of an 8.0-day-old embryo; the surrounding ectoderm is indicated by arrowheads. Bar in J represents $35 \mu \mathrm{m}$ (for A, B, D, E, G, H, J, K); bar in $L$ represents 20 $\mu \mathrm{m}$ (for C, F, I, L). Abbreviations: ec, endocardium; hm, head mesenchyme; hg, hindgut; mc, myocardium; ne, neuroectoderm; so, somite; tc, telocoel. The schematic drawing is a ventral view of an 8.0- to 8.5-day-old embryo. The planes of the sections are indicated by the corresponding letters of the micrographs. The right schematic drawing represents a more mid-sagittal section as shown in micrographs $\mathrm{A}$ to $\mathrm{C}, \mathrm{H}$ and $\mathbf{I}$. 
detectable in the bulk of the embryonic tissue. By comparing consecutive sections stained with N-CAM- or PSA-specific antibodies, no tissues positive for PSA but negative for N-CAM could be detected.

Embryonic day 9.0 to 9.5. The 9.0-day-old embryo contains 13 to 20 somites. The neural tube is now closed with the exception of the posterior neuropore and the roof of the myelencephalon. The optic, otic, and olfactory sense organ primordia have formed. The heart begins to beat and three paired aortic arches are present. The forelimb buds begin to develop at the level of somites 8 to 12 . The 9.5 -day embryo contains 21 to 29 somites. Anterior somites start to differentiate into their dermatomic, myotomic, and sclerotomic parts. The posterior neuropore closes and the brain vesicles separate and form the four major divisions of the brain (prosen-, mesen-, meten-, and myelencephalon).

At $\mathrm{E} 9.0$ and $9.5 \mathrm{~N}-\mathrm{CAM}$ is strongly expressed in all main brain regions (Figs. 4A,D), in the neural tube which will form the spinal cord, as well as in the neural plate in the posterior part of the embryo (Figs. 4C,F). Additionally, a high expression of N-CAM could be found in somites (Figs. 4B,E), heart, and extrasomitic mesoderm. Younger, epithelial somites were more strongly positive than differentiating somites. In differentiating somites the dermamyotome showed a higher degree of N-CAM expression than the sclerotome (Figs. $4 B, E)$. N-CAM was expressed only weakly in the otic and optic vesicle (not shown) and was undetectable in the endoderm of the fore- and hindgut and endothelial cells of the arteries (Figs. 4C,F).

Like N-CAM, PSA was detectable in all main parts of the developing brain (Figs. $4 \mathrm{G}, \mathrm{J}$ ), in the spinal cord, the neural plate in the posterior body region (Figs. 4I,L), and in heart tissue and somites (Figs. $4 \mathrm{H}, \mathrm{K}$ ). The distribution of PSA in somites was comparable to that of $\mathrm{N}$-CAM. PSA was only weakly detectable in the otic and optic vesicle as well as in the surrounding mesoderm (Figs. 4G,J). As for E 8.0 and 8.5 a high background label was found in the gut endoderm which made it impossible to analyze the localization of PSA in this tissue.

\section{DISCUSSION}

In the present study we have analyzed the expression pattern of N-CAM and PSA during early embryogenesis ( $E 7.5$ to $E 11.0$ ) of the mouse by Western and Northern blot analyses as well as by immunohistochemical techniques. By indirect immunohistochemistry, from E 8.0 onwards, N-CAM and PSA were detectable in the bulk of embryonic tissue. In contrast, by Western blot analysis of tissue extracts from E 8.0 to E 9.5 only the 180 and $140 \mathrm{kD} \mathrm{L-N-CAM}$ isoforms were present and substantial amounts of PSA-expressing proteins could not be detected before E 10.0 .

Since by indirect immunofluorescence PSA was found to be widely distributed in the embryonic tissue at E 8.0, it is unlikely that Western blot analysis was not sensitive enough to detect protein-associated PSA. So far, two PSA-expressing glycoproteins have been described: N-CAM and the alpha subunit of voltage gated sodium channels (Finne et al., 1983; Zuber et al., 1992). According to its apparent MW (a smear starting at 250 $\mathrm{kD}$ upwards) the latter one should also be detectable under the SDS-PAGE conditions used (Zuber et al., 1992). However, it is not known whether sodium channels are expressed during such early embryonic stages in the mouse (for review, see Mandel, 1992). There are two possible ways to explain the discrepancies between the findings by indirect immunohistochemistry and Western blot analysis: First, PSA is enzymatically degraded during tissue preparation and, therefore, is not detectable in Western blots. This enzymatic activity, however, should then be predominantly present between E 8.0 and E 9.5, since later during development, PSA-positive glycoproteins, represented by N-CAM or other, still unknown glycoproteins in the same molecular weight range can easily be detected in tissue extracts (see Fig. 1). Second, PSA is present on molecules which either cannot penetrate the SDS gels used, such as proteoglycans, or it is carried by glycolipids which are not detectable by SDSPAGE. We have addressed the second possibility, and analyzed the immunoreactivity of 735 antibody on polar glycolipid fractions from 8.5- to 9.5-day-old mouse embryos separated by thin layer chromatography according to Rougon et al. (1986). Under these experimental conditions we were not able to detect PSA-positive glycolipids (Probstmeier, unpublished observations). Independently of these possibilities we have to conclude that PSA expression, at least during embryonic development of the mouse, cannot be extensively studied only by Western blot analysis. Since comparable embryological studies in frog and chicken were restricted to Western blot analysis (Levi et al., 1987; Sunshine et al., 1987), it remains to be determined if the phenomenon described here, i.e. a prominent expression of PSA during early embryonic stages detectable by immunohistochemistry but not by Western blots, can also be observed in other species. To our knowledge, only one example related to this problem has been described. Schlosshauer and coworkers (1984) have shown by Western blot analysis that at $\mathrm{E} 10$ in the optic fiber layer of the chicken retina only L-N-CAM forms are present. In contrast to these findings, immunohistological studies by others have demonstrated a strong staining with a PSA-specific antibody at E 10 in the optic fiber layer of chicken retina (Doherty et. al., 1990). 

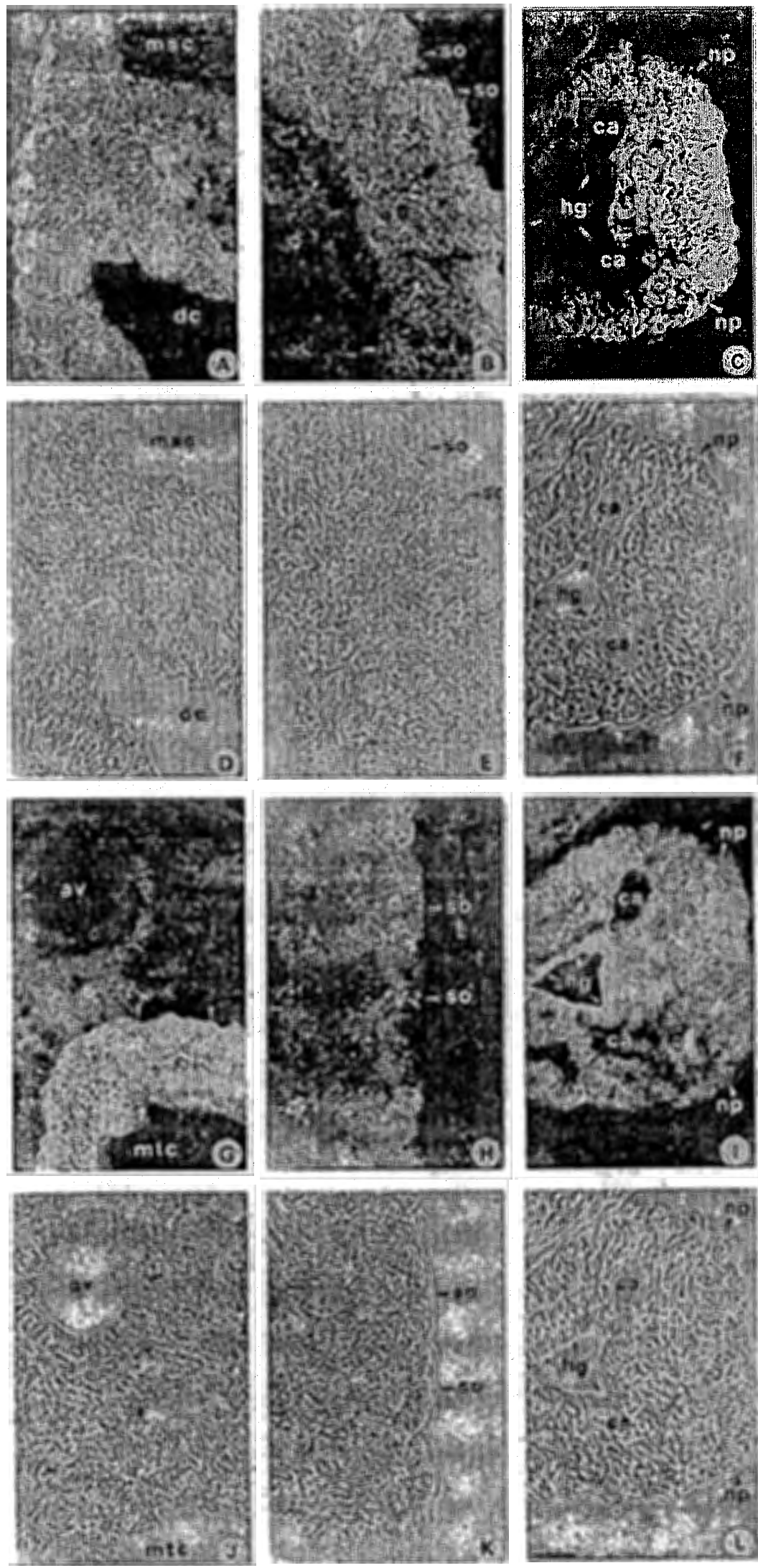

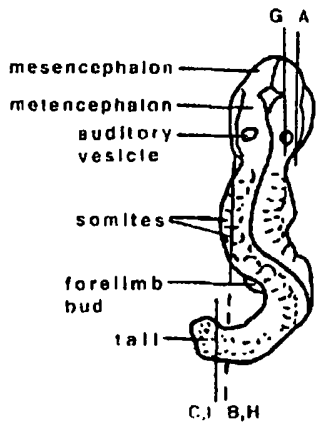

Fig. 4. Immunohistological localization of N-CAM (A, B, C) and PSA (G, H, I) in sections of 9.0- $(\mathrm{C}, \mathrm{I})$ and 9.5- $(\mathrm{A}, \mathrm{B}$, G, H) day-old mouse embryos. D, E, F, $J, K$, and $L$ are the corresponding phasecontrast micrographs to fluorescence images in $\mathrm{A}, \mathrm{B}, \mathrm{C}, \mathrm{G}, \mathrm{H}$, and $\mathrm{I}$, respectively. A,D: Sagittal section of the head region of a 9.5-day-old embryo.

$\mathbf{B , E , H , K}$ : Sagittal section of somites of a 9.5-day-old embryo in the region of the forelimb bud. Arrows indicate the inner border of the somites. C,F,I,L: Cross section of the posterior part of a 9.0-dayold embryo. The borders of the neural plate are indicated by arrowheads, the endoderm of the hindgut by arrows. G,J: Sagittal section of the head region of a 9.5-day-old embryo. The borderline of the metencephalon (arrowheads) and of the auditory vesicle (arrows) are indicated. Bar in L represents $35 \mu \mathrm{m}$ (A to L). Abbreviations: av, auditory vesicle; ca, caudal aorta; dc, diencoel; hg, hindgut; msc, mesencoel; mtc, metocoel; np, neural plate; so, somile. The schematic drawing shows a dorsal view of a 9.0day-old embryo. The planes of the sections are indicated by the corresponding letters of the micrographs. 
During the embryonic stages analyzed by immunohistochemistry (E 8.0 to E 9.5) the expression of PSA strongly correlated with the expression of N-CAM, i.e. no tissue was detectable which was positive for PSA but negative for N-CAM. This principle is not conserved during later developmental stages as, for example, in the adult rat brain, where PSA but not N-CAM is expressed on some cell populations of the main and accessory olfactory bulbs (Zuber et al., 1992).

What are the functional aspects of the PSA expression on the cell surface? On the molecular level, it has been shown that homotypic aggregation of N-CAM containing liposomes is decreased when PSA-bearing $\mathrm{N}$-CAM is used (Hoffman and Edelman, 1983). Since $\mathrm{N}$-CAM can interact with a number of other molecules such as Ll (Kadmon et al., 1990a,b), glycosaminoglycans (Cole and Akeson, 1989), and collagens (Probstmeier et al., 1992), it is possible that these heterophilic interactions are also influenced by PSA. In the mouse, modulation of the interaction possibilities of N-CAM by PSA may play a role only during late embryonic development since in earlier stages only L-N-CAM isoforms are present. Whatever the molecular nature of PSA-bearing molecules, at the cellular level PSA may be involved in keeping space between adjacent cells (Yang et al., 1992). An increased distance between opposed cell membranes must not necessarily correlate with a decrease in intercellular adhesion. As already suggested by Yang et al. (1992), an increase in the intercellular space may even provide the "right" distance for certain ligand-receptor pairs at the surfaces of opposed cells to interact with each other. In this context, however, the presence of PSA on the surface of epithelial somite cells is difficult to understand since these cells show a close cell to cell contact which is further strengthened by the presence of tight junctions (for review, see Keynes and Stern, 1988). Furthermore, it is likely that epithelization of the segmental plate in the chicken correlates with a strengthened cell to cell adhesion (Cheney and Lash, 1984). According to our results the slaining intensity of 735 antibody is (1) in somites at least not weaker than in the unsegmented mesoderm and, (2) in younger somites more intense than in older ones. However, staining intensities do not allow to evaluate the amount and local density of PSA present on somitic cells. Assuming that a critical value of PSA molecules has to be exceeded to increase the intercellular space, it is also possible that this threshold is not reached on these cells. Independently of its involvement in recognition or adhesion PSA can also influence other cellular processes as demonstrated by the finding that removal of PSA modifies the function of sodium channels (Recio-Pinto et al., 1990).

Of the three major N-CAM isoforms only the 180 (N-CAM 180) and $140 \mathrm{kD}$ (N-CAM 140) components but not the $120 \mathrm{kD}$ (N-CAM 120) component were detectable in Western blots of mouse tissue extracts from $\mathrm{E}$ 8.0 to E 11.5. N-CAM 180 and N-CAM 140 are integral membrane glycoproteins which differ in the length of their cytoplasmic tails (Gennarini et al., 1984; Murray et al., 1986), whereas N-CAM 120 is linked to the plasma membrane via a glycophosphatidylinositol (GPI) anchor (He et al., 1986; Sadoul et al., 1986). This suggests that the intracellular parts of N-CAM 180 and 140 are essential for the function of the molecule during early embryonic development which cannot be fulfilled by N-CAM 120 , such as interactions with cytoskeletal components (Pollerberg et al., 1986) and/or the triggering of specific second messenger systems (Schuch et al., 1989; Doherty et al., 1991a). Another possibility is that the function of the GPI-linked N-CAM 120 isoform is related to morphogenetic processes which take place in much later developmental stages.

By indirect immunofluorescence we were not able to detect N-CAM or PSA at E 7.5, the stage of neural induction. This could argue for species differences in the time course of N-CAM expression. For chicken, it has been shown that N-CAM is already present at the blastoderm stage (Thiery et al., 1982; Crossin et al., 1985), and in Pleurodeles waltl (Urodele, amphibian) N-CAM was detectable in the early gastrula before neural induction (Saint-Jeannet et al., 1989). For Xenopus laevis the data are contradictory: On the protein (Balak et al., 1987; Jacobson and Rutishauser, 1986) as well as on the mRNA (Kintner and Melton, 1987) level no expression of N-CAM was detectable before the onset of neural induction. In contrast, Levi et al. (1987) detected N-CAM immunohistologically before the gastrula stage. In this context, we cannot completely rule out that in the mouse low amounts of N-CAM and/or PSA are present in $\mathrm{E} 7.5$ but not revealed by the antibodies used in the present study.

In summary, our study has shown that by immunohistological techniques PSA is already expressed during early embryonic development in the mouse, i.e. at or shortly after the onset of neural induction. In contrast, by Western blot analysis of whole embryos PSA was found not to be expressed on N-CAM which is present only in its lightly sialylated isoforms of 140 and $180 \mathrm{kD}$. The molecules carrying PSA and their possible function during early embryogenesis still remain to be determined.

\section{ACKNOWLEDGMENTS}

We are grateful to $M$. Schachner for financial support and stimulating discussions, D. Bitter-Suermann for antibodies, C. Goridis for the N-CAM-specific cDNA clone M1.3, K. Kratochwil for valuable advice, and 
Deutsche Forschungsgemeinschaft (post-doctoral fellowships to R.P. and J.S.-S.) for support.

\section{REFERENCES}

Acheson A, Sunshinc JL, Rutishauser U (1991): NCAM polysialic acid can regulate both cell-cell and cell-substrate interactions. J Cell Biol 114:143-153.

Balak K, Jacobson M, Sunshine J, Rutishauser U (1987): Neural cell adhesion molecule expression in Xenopus embryos. Dev Biol 119:540-550.

Barbas JA, Chaix J-C, Steinmetz M, Goridis C (1988): Differential splicing and alternative polyadenylation generates distinct NCAM transcripts and proteins in the mouse. EMBO J 7:625632.

Barthels D, Santoni MJ, Wille W, Ruppert C, Chaix JC, Hirsch MR, Fontecilla-Camps JC, Goridis C (1987): Isolation and nucleotide sequence of mouse NCAM cDNA that codes for a $\mathrm{Mr}$ 79,000 without a membrane-spanning region. EMBO J 6:907914.

Bartsch U, Kirchhoff F, Schachner M (1990): Highly sialylated $\mathrm{N}$-CAM is expressed in adult mouse optic nerve and retina. J Neurocytol 19:550-565.

Bradford MM (1976): A rapid and sensitive method for the quantitation of microgram quantities of protein using the principle of protein-dye binding. Anal Biochem 72:248-254.

Cheney CM, Lash JW (1984): An increase in cell-cell adhesion in the chick segmental plate results in a meristic pattern. J Embryol Exp Morphol 79:1-10

Chirgwin JM, Przybyla AE, McDonald RJ, Rutter WJ (1979): Isolation of biologically active ribonucleic acids from sources enriched in ribonuclease. Biochemistry 18:5294-5299.

Cole GJ, Akeson R (1989): Identification of a heparin binding domain of the neural cell adhesion molecule N-CAM using synthetic peptides. Neuron 2:1157-1165.

Cole GJ, Loewy A, Glaser L (1986): Neuronal cell-cell adhesion depends on interactions of N-CAM with heparin-like molecules. Nature 320:445-447.

Crossin KL, Chuong C-M, Edelman GM (1985): Expression sequences of cell adhesion molecules. Proc Natl Acad Sci USA 82:6942-6946.

Cunningham BA, Hoffman S, Rutishauser U, Hemperly JJ, Edelman GM (1983): Molecular topography of the neural cell adhesion molecule N-CAM: Surface orientation and location of sialic acid-rich and binding regions. Proc Natl Acad Sci USA 80: 3116-3120.

Cunningham BA, Hemperly JJ, Murray BA, Prediger EA, Brackenbury R, Edelman GM (1987): Neural cell adhesion molecule: Structure, immunoglobulin-like domains, cell surface modulation, and alternative RNA splicing. Science 236:799-806.

Doherty P, Cohen J, Walsh FS (1990): Neurite outgrowth in response to transfected N-CAM changes during development and is modulated by polysialic acid. Neuron 5:209-219.

Doherty P, Ashton SV, Moore SE, Walsh FS (1991a): Morphoregulatory activities of NCAM and N-cadherin can be accounted for by $\mathrm{G}$-protein dependent activation of $\mathrm{L}$ - and $\mathrm{N}$-type neuronal calcium channels. Cell 67:21-23.

Doherty P, Rowett LH, Moore SE, Mann DA, Walsh FS (199b): Neurite outgrowth in response to transfected N-CAM and $\mathrm{N}$-cadherin reveals fundamental differences in neuronal responsiveness to CAMs. Neuron 6:247-258.

Faissner A, Teplow DB, Kübler D, Keilhauer G, Kinzel V, Schachner
M (1985): Biosynthesis and membrane topography of the neural cell adhesion molecule L1. EMBO J 4:3105-3113.

Finne J, Bitter-Suermann D, Goridis C, Finne U (1987): An lgM monoclonal antibody to group $B$ meningococci crossreacts with developmentally regulated polysialic acid units of glycoproteins in neural and extraneural tissues. J Immunol 138:44024407.

Finne J, Finne U, Deagostini-Bazin H, Goridis C (1983): Occurrence of alpha 2-8 linked polysialosyl units in a neural cell adhesion molecule. Biochem Biophys Res Commun 112:482-487.

Fort P, Marty L, Piechaczyk M, Eisabrouty S, Dani C, Jeanteur P, Blanchard JM (1985): Various rat adult tissues express only one major mRNA species from the glyceraldehyde-3-phosphatedehydrogenase family. Nucleic Acids Res 13:1431-1442.

Frei T, von Bohlen und Halbach F, Wille W, Schachner M (1992): Different extracellular domains of the neural cell adhesion molecule (N-CAM) are involved in different functions. J Cell Biol 118:177-194.

Frosch M, Görgen J, Boulnois GG, Timmis KN, Bitter-Suermann D (1985): NZB mousc system for production of monoclonal antibodies to weak bacterial antigens: Isolation of an IgG antibody for the polysaccharide capsules of Escherichia coli $\mathrm{Kl}$ and group B meningococci. Proc Natl Acad Sci USA 82:11941198.

Gennarini G, Hirn M, Deagostini-Bazin H, Goridis C (1984): Studies on the transmembrane disposition of the neural cell adhesion molcculc N-CAM. The use of liposome-inserted radioiodinated N-CAM to study its transbilayer-orientation. Eur J Biochem 142:65-73.

Goridis C, Hirn M, Santoni M-J, Gennarini G, Deagostini-Bazin H Jordan BR, Kiefer M, Steinmetz M (1985): Isolation of mouse N-CAM-related cDNA: Detection and cloning using monoclonal antibodies. EMBO J 4:631-635.

He HT, Barbet J, Chaix JC, Goridis C (1986): Phosphatidylinositol is involved in the membrane attachment of N-CAM 120, the smallest component of the neural cell adhesion molecule. EMBO J 5:2489-2494.

Hoffman S, Edelman GM (1983): Kinetics of homophilic binding by $E$ and $A$ forms of the neural cell adhesion molecule. Proc Natl Acad Sci USA 80:5762-5766

Husmann M, Görgen I, Weisgerber C, Bitter-Suermann D (1989): Up-regulation of cmbryonic NCAM in an EC cell line by retinoic acid. Dev Biol 136:194-200.

Jacobson M, Rutishauser $U$ (1987): Induction of neural cell adhesion molecule (N-CAM) in Xenopus embryos. Dev Biol 116:524531 .

Jamcs WM, Agnew WS (1987): Multiple oligosaccharide chains in the voltage-sensitive $\mathrm{Na}$ channel from Electrophorus electricus: Evidence for alpha 2,8-linked polysialic acid. Biochem Biophys Res Commun 148:817-826.

Kadmon G, Kowitz A, Altevogt P, Schachner M (1990a): The neura cell adhesion molecule N-CAM enhances L1-dependent cellcell interactions. J Cell Biol 110:193-208.

Kadmon G, Kowitz A, Altevogt P, Schachner M (1990b): Functional conperation between the neural cell adhesion molecules $\mathrm{Ll}$ and N-CAM is carbohydrate dependent. J Cell Biol 110:209-218.

Key B, Akeson RA (1991): Delineation of olfactory pathways in the frog nervous system by unique glycoconjugates and N-CAM glycoforms. Neuron 6:381-396.

Keynes RJ, Stern CD (1988): Mechanisms of vertebrate segmentation Development 103:413-429.

Kintner CR, Melton DA (1987): Expression of Xenopus N-CAM RNA in ectoderm is an early response to neural induction. Development 99:311-325. 
Laemmli UK (1970): Cleavage of structural proteins during the assembly of the head of bacteriophage T4. Nature 227:680-685.

Levi G, Crossin KL, Edelman GM (1987): Expression sequences and distribution of two primary cell adhesion molecules during embryogenesis of Xenopus laevis. J Cell Biol 105:2359-2372.

Mandel G (1992): Tissue-specific expression of the voltage-sensitive sodium channel. J Member Biol 125:193-205.

Maniatis T, Fritsch EF, Sambrook J (1982): Molecular cloning. A laboratory manual. Cold Spring Harbor, New York: Cold Spring Harbor Laboratory.

Melton DA, Krieg PA, Rebagliati MR, Maniatis T, Zinn K, Gleen MR (1984): Efficient in vitro synthesis of biologically active RNA and RNA hybridization probes from plasmids containing a bacteriophage SP6 promoter. Nucleic Acids Res 12:70357056.

Miragall F, Kadmon G, Husmann M, Schachner M (1988): Expression of cell adhesion molecules in the olfactory system of the adult mouse: Presence of the embryonic form of N-CAM. Dev Biol 129:516-531.

Miragall F, Kadmon G, Faissner A, Schachner M (1990): Retention of $\mathrm{J} /$ tenascin and the polysialyated form of the neural cell adhesion molecule (N-CAM) in the adult olfactory bulb. J Neurocytol 19:899-914.

Murray B, Owens GC, Prediger EA, Edelman GM, Cunningham BA (1986): Alternatively spliced mRNAs code for different polypeptide chains of the chicken neural cell adhesion molecule (N-CAM). J Cell Biol 102:189-193.

Pollerberg EG, Schachner M, Davoust J (1986): Differentiation statedependent surface mobilities of two forms of the neural cell adhesion molecule. Nature 324:462-465.

Probstmeier R, Fahrig T, Spiess E, Schachner M (1992): Interactions of the neural cell adhesion molecule and the myelin-associated glycoprotein with collagen type I: Involvement in fibrillogenesis. J Cell Biol 116:1063-1070.

Recio-Pinto E, Thornhill WB, Duch DS, Levinson SR, Urban BW (1990): Neuraminidase treatment modifies the function of electroplax sodium channels in planar lipid bilayers. Neuron 5:675-684.

Rothbard JB, Brackenbury R, Cunningham BA, Edelman GM (1982): Differences in the carbohydrate structures of neural cell adhesion molecules from adult and embryonic chicken brains. J Biol Chem 257:11064-11069.

Rougon G, Deagostini-Bazin H, Hirn M, Goridis C (1982): Tissueand developmental-stage-specific forms of a neural cell surface antigen linked to differences in glycosylation of a common polypeptide. EMBO J 1:1239-1244

Rougon G, Dubois C, Buckley N, Magnani JL, Zollinger W (1986): A monoclonal antibody against meningococcus group $B$ polysaccarides distinguishes embryonic from adult N-CAM. J Cell Biol 103:2429-2437.

Rutishauser U, Acheson A, Hall AK, Mann DM, Sunshine J (1988):
The neural cell adhesion molecule (N-CAM) as a regulator of cell-cell interaction. Science 240:53-57.

Sadoul R, Hirn M, Deagostini-Bazin H, Rougon G, Goridis C (1983): Adult and embryonic mouse neural cell adhesion molecules have different binding properties. Nature 304:347-349.

Schlosshauer B, Schwarz U, Rutishauser U (1984): Topological distribution of different forms of neural cell adhesion molecule in the developing chick visual system. Nature 310:141-143.

Saint-Jeannet J-P, Foulquier F, Goridis C, Duprat A-M (1989): Expression of N-CAM precedes neural induction in Pleurodeles waltl (urodele, amphibian). Development 106:675-683.

Schuch U, Lohse MJ, Schachner M (1989): Neural cell adhesion molecules influence second messenger systems. Neuron 3:1320.

Sorkin BC, Hoffman S, Edelman GM, Cunningham BA (1984); Sulfation and phosphorylation of the neural cell adhesion molecule, N-CAM. Science 225:1476-1478.

Sunshine J, Balak K, Rutishauser U, Jacobson M (1987): Changes in neural cell adhesion molecule (N-CAM) structure during vertebrate neural development. Proc Natl Acad Sci USA 84:59865990.

Tacke R, Moos M, Teplow DB, Früh K, Scherer H, Bach A, Scliachner M (1987): Identification of cDNA clones of the mouse neural cell adhesion molecule L1. Neurosci Lett 82:8994.

Theodosis DT, Rougon G, Poulain DA (1991): Retention of embryonic features by an adult neuronal system capable of plasticity: Polysialylated neural cell adhesion molecule in the hypothalamo-neurohypophysial system. Proc Natl Acad Sci USA 88:5494-5498

Thiery JP, Duband J, Rutishauser U, Edelman GM (1982): Cell adhesion molecules in early chicken embryogenesis. Proc Natl Acad Sci USA 79:6737-6741.

Towbin H, Staehelin T, Gordon J (1979): Electrophoretic transfer of proteins from polyacrylamide gels to nitrocelfulose sheets: procedure and some applications. Proc Natl Acad Sci USA 76: 4350-4354.

Walsh FS, Parekh RB, Moore SE, Dickson G, Barton CH, Gower HJ, Dwek RA, Rademacher TW (1989): Tissue specific O-linked glycosylation of the neural cell adhesion molecule (N-CAM). Development 105:803-811.

Yang P, Yin X, Rutishauser U (1992): Intercellular space is affected by the polysialic-acid content of N-CAM. J Cell Biol 116: 1487-1496.

Zhang H, Miller RH, Rutishauser U (1992): Polysialic acid is required for optimal growth of axons on a neural substrate. J Neurosci 12:3107-3114.

Zuber C, Lackie PM, Catterall WA, Roth J (1992): Polysialic acid is associated with sodium channels and the neural cell adhesion molecule N-CAM in adult rat brain. J Biol Chem 267:99659971. 